\title{
ESTRUTURA DA CROSTA NO SUDESTE E CENTRO-OESTE DO BRASIL, USANDO FUNÇÃO DO RECEPTOR LOCAL: SÃO PAULO
}

\author{
George Sand Leão Araújo de França \\ Orientador: Dr. Marcelo Sousa de Assumpção (IAG/USP) \\ $143 p$ - Tese (Doutorado) - Defesa 23.05.2003
}

RESUMO. 0 estudo da estrutura da crosta usando a função do receptor é realizado com a onda $\mathrm{P}$ de telessismo que atinge a base da crosta, sob a estação, com um ângulo próximo da vertical. Parte da energia da onda P é convertida em São refratar na descontinuidade da Moho (denominada onda PS) e também em reflexões múltiplas. Através da deconvolução da componente horizontal pela vertical, obtém-se a função do receptor, que apresenta um pico maior correspondente à $\mathrm{P}$ direta seguido por picos menores que as ondas Ps, as ondas convertidas e reverberadas na crosta. Foram analisadas um total de 24 estações sobre o Sudeste e Centro-Oeste do Brasil. Para realçar reflexões múltiplas, foi utilizado 0 empilhamento inclinado ponderado pela fase. A fase múltipla e a Ps permitem estimar a razão vp/vs em cada estação Na Bacia do Paraná, a espessura média obtida é de 44 Km com razão vp/vs aumentando em direção ao eixo da Bacia (de 1,71 para 1,77). Na Faixa Ribeira, a espessura média longe da crosta foi de $37 \mathrm{~km}$ e razão $=2,81$. Próximo ao Cráton do São Francisco, a espessura média foi de $40 \mathrm{~km}$ e razão $=1,70$, e na costa foi de 34 km e razão $=1,73$. $\mathrm{Na}$ Faixa Brazilia e adjacencias, a crosta é mais heterogênia, com espessura variando de 32 a 42 km e razão variando de 1,68 a 1,88. Para cada região foram estimadas, de acordo com a razão vp/vs e velocidade da onda P, as prováveis composições para a crosta inferior.

ABSTRACT. The study of the crustal structure using receiver function is accomplished with the teleseismic $P$ wave that reaches the base of the crust with a steep angle. Part of the energy the $P$ wave is converted into $S$ when refracting in the Moho descontinuity (Ps wave) and also into multiple reflections. Through the deconvolution of the horizontal with the vertical component, the receiver function is obtained, which presents a large peak for the direct $P$ followed by smaller peaks (Ps waves) of converted waves and reverberation in the crust. The receiver function technique has been used broadly to estimate the crustal structure under broad-band stations. 24 stations in the SE and Central Brazil were analyzed. The multiple reflections are enhanced with the slant stacking which uses the phase as weight. Then we obtain the estimates of the converted phases and have an estimate of the vp/vs ratio beneth each station. In the Paraná Basin, the average thickness is $44 \mathrm{~km}$ with a vp/vs ratio increasing towards the axis of the Basin (from 1,71 to 1,77 ). In the Ribeira belt, the thickness far from the coast is $37 \mathrm{~km}$ and ratio $=1,81$. Close to the San Francisco Craton, the average thickness is $40 \mathrm{~km}$ and ratio $=1,70$, and near the coast, it is $34 \mathrm{~km}$ and ratio $=1,73$. The Brasilia belt is much more heterogeneous, with thicknesses varying from 32 to $42 \mathrm{~km}$ and ratios varying from 1,68 to 1,88. For each area the vp/vs ratio and $\mathrm{P}$ wave velocity were used to infer the probable composition for the lower crust. 